\title{
Survey finds US public still supports science
}

\section{Researchers question meaning of an apparent opinion gap between scientists and the public.}

\section{Erika Check Hayden}

29 January 2015

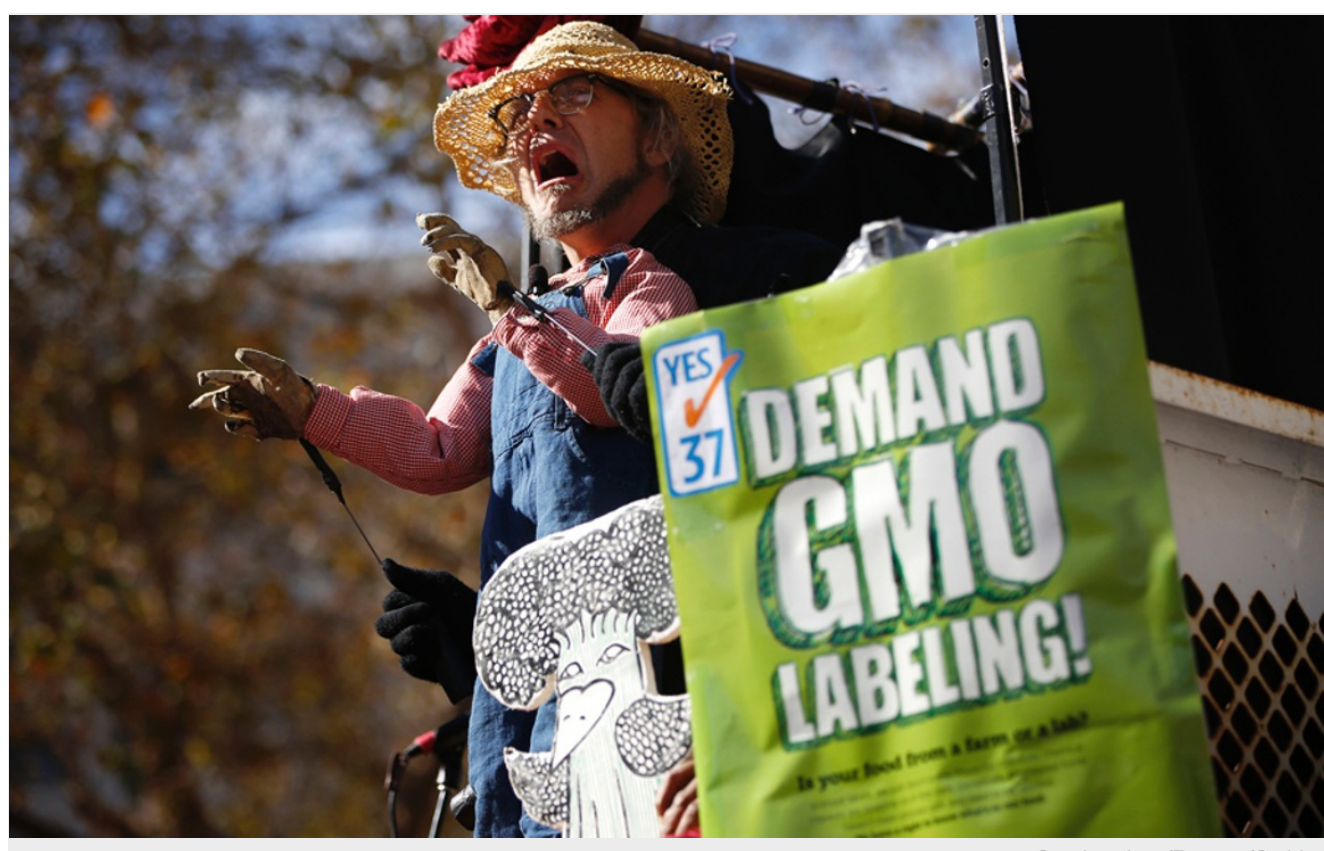

Stephan Lam/Reuters/Corbis

Scientists and the public differ in their perception of the safety of genetically modified foods.

The US public trusts scientists and supports science. But scientists and non-scientists are concerned about the state of children's science education, and researchers are dismayed about the state of US science, according to a poll released on 29 January.

Out of 2,002 US adults questioned in the survey, $79 \%$ say that science has made life easier for most people, and $71 \%$ of those polled say that government investments in basic scientific research usually pay off. But just $16 \%$ of 3,748 scientists surveyed and $29 \%$ of the public rank US education in science, technology, engineering and maths in elementary and high school as above average or as the best in the world. And $52 \%$ of scientists surveyed said that this is generally a good time for science, down from $76 \%$ in a similar survey conducted in 2009.

"This is a time of distress for the scientific community," says Alan Leshner, chief executive of the American Association for the Advancement of Science (AAAS), which produced the survey with the Pew Research Center, a non-partisan think tank in Washington DC.

Members of the public were surveyed by telephone in August, and the scientists — all US members of the AAAS — were surveyed online in September and October. The margin of error for the total sample was $\pm 3.1 \%$.

\section{Difference of opinion}

The poll seems to reveal large gaps between scientists and the public when it comes to their opinions on a range of hotly debated scientific issues, such as climate change, evolution and the safety of genetically modified (GM) foods. For instance, $50 \%$ of the public and $87 \%$ of scientists say that climate change is mostly due to human activity; $65 \%$ of the public and $98 \%$ of scientists say that humans have evolved over time; $37 \%$ of the public and $88 \%$ of scientists say it is safe to eat GM foods; and $47 \%$ of the public and $89 \%$ of scientists favour the use of animals in research.

Leshner argues that these apparent gaps should spur further science-education efforts. "There has to be a set of ready receptors for what science is showing, or the benefits are diminished," he says. 
But Daniel Sarewitz, a geoscientist and co-director of the Consortium for Science, Policy and Outcomes at Arizona State University in Tempe, says that these putative differences in opinion might be driven by factors not examined by the survey — for instance, greater religious, economic and sociocultural homogeneity among scientists than among the general public. He questions the decision to lump scientists from different disciplines together in the poll.

“The very exercise itself is aimed, perhaps unintentionally, at perpetuating the lie that 'science' is one unified enterprise that can be meaningfully isolated from society, and that scientists' views about issues outside of their specific domain of expertise are more imbued with objectivity and less clouded by bias or ignorance than the unwashed 'public'," Sarewitz says.

\section{Support for science}

Dan Kahan, who teaches law and psychology at Yale Law School in New Haven, Connecticut, disagrees with the report's interpretation that these differences in opinion are due to public distrust in science.

For instance, the report notes that in 2014, the proportion of American adults who said that US science achievements are "the best in the world" or "above average" dropped to $54 \%$, down from $65 \%$ in 2009. But, says Kahan, that is not a meaningful difference. And the other indicators in the report speak of strong support among the public for US science — for instance, between roughly $60 \%$ and $80 \%$ of the public say that science has a mostly positive effect on health care, food and the environment.

"This report shows that Americans basically love science," Kahan says. "Yet there is a kind of common wisdom out there that attributes public disputes over science to 'distrust of scientists'. There's no evidence for that."

For example, he says, a 2009 Pew report found that a majority of people who held opposing views on how humans originated both said that scientists have contributed "a lot" to society, with $78 \%$ of believers in evolution and $63 \%$ of creationists having the same positive view of scientists. The report noted the same trend among those who did or did not believe that humans are causing climate warming, with $74 \%$ of believers and $64 \%$ of non-believers seeing scientists' contributions as positive.

\section{Cultural cognition}

Kahan says that people do trust science, but that they tend to selectively accept information that supports the views of particular cultural, religious and political groups on these issues — an idea known as cultural cognition theory. He disputes the 'information deficit model' - the idea that more education about scientific topics will change people's views — arguing that more information will not change people's minds as long as their membership in identity groups depends on them holding particular views.

"People have a big stake in protecting their membership to these defining groups," Kahan says.

Barry Bozeman, a political scientist at Arizona State University in Phoenix, says that the opinions of the general public — such as the people surveyed in this study — increasingly matter less to policy-making than the opinions of people belonging to these identity groups, some of which are more organized and active in politics than are average citizens.

'I'm less interested in the differences between citizens' and scientists' opinions than in differences of opinion among highly diverse and differentially informed groups of citizens," Bozeman says. "What these people think about, say, global warming or US scientific competitiveness matters greatly because, for better or worse, they have the attention of policy-makers."

Nature | doi:10.1038/nature.2015.16818 